\title{
Chapter 2 \\ Responses to the Middle-Income Trap \\ in China, Malaysia, and Thailand
}

\author{
Akira Suehiro
}

\subsection{Rethinking the Middle-Income Trap}

\subsubsection{Studies on the "Middle-Income Trap"}

Starting around the end of the 2000s, a certain term was often used in discussions about emerging Asian countries. This was the "middle-income trap," a favored term of economists at international institutions and in American think tanks.

For example, in Asia 2050 (ADB 2012a), the Asian Development Bank (ADB) provided two long-term forecasts for Asia as a whole, giving an optimistic scenario (the Asian century) and a pessimistic scenario (the risk of getting caught in a middleincome trap). The ADB addressed this issue in relation to China in 2012 in Growing Beyond the Low-Cost Advantage: How the People's Republic of China Can Avoid the Middle-Income Trap (ADB 2012b). They suggested the path that China could take to upgrade from an upper-middle-income country to a high-income country through a combination of four elements: technically advanced domestic firms, high-value goods and services, developed markets, and innovation in products and processes (ADB 2012b, p. 11).

That same year, the World Bank raised the same issue in a report titled China 2030: Building a Modern, Harmonious, and Creative High-Income Society (World Bank et al. 2012). They pointed out the difficulty involved for middle-income countries to shift to high-income countries. In fact, among 101 middle-income countries or economies in 1960 , only thirteen countries or economies could reach the high-income

\footnotetext{
${ }^{1}$ This literature includes the World Bank (Yusuf and Evenett 2002; Gill and Kharas 2007), IMF (Aiyar et al. 2013), the National Bureau of Economic Research (Eichengreen et al. 2013), and the Levy Economics Institute of Bard College (Felipe et al. 2012).
}

\footnotetext{
A. Suehiro (凶)

Faculty of International Social Sciences, Gakushuin University, Tokyo, Japan

e-mail: asuehiro0830@gmail.com

(C) The Author(s) 2019

K. Tsunekawa and Y. Todo (eds.), Emerging States at Crossroads,

Emerging-Economy State and International Policy Studies,

https://doi.org/10.1007/978-981-13-2859-6_2
} 
level in 2008, namely Equatorial Guinea, Greece, Hong Kong, Ireland, Israel, Japan, South Korea, Mauritius, Portugal, Puerto Rico, Singapore, Spain, and Taiwan (ADB 2012b, p. 12). Four out of those thirteen (Hong Kong, South Korea, Singapore, and Taiwan) belong to the so-called Asian newly industrialized economies, or the Asian NIEs (Suehiro 2008).

The term middle-income trap was first used by the World Bank's Gill and Kharas in An East Asian Renaissance (Gill and Kharas 2007). They argued that three transformations were required for emerging Asian countries (middle-income countries) to continue their growth: (1) transformation from diversification to more specialization in production and employment; (2) transformation from a focus on investment to a focus on innovation; and (3) a shift from equipping workers with skills to adjust to new technologies to preparing them to shape new products and processes. Gill and Kharas sounded a warning that economic growth in these countries would be sluggish without steady progress through these three transformations and that the emerging Asian countries would be caught in a middle-income trap, as is the current situation for many middle-income countries in the Middle East and Latin America (Gill and Kharas 2007, pp. 17-18).

Likewise, Eichengreen et al. (2013) defined countries suffering the middle-income trap as those that had undergone average GDP growth of at least $3.5 \%$ for several years and subsequently stepped down by at least $2 \%$ between seven-year periods. Similar observations are shared by Felipe and his colleagues (2012) and Veerayooth (2015).

In particular, the study of Felipe and his colleagues notably explored the issue of middle-income trap by employing two major criteria: the income range used to distinguish a middle-income country, and the average duration of stagnation in the same category of middle-income country on the basis of past experiences. They surveyed 124 countries or economies and categorized middle-income countries as those having GDP per capita of between \$2,000 and \$11,749 in terms of 1990 PPP (purchasing power parity) U.S. dollars. ${ }^{2}$ They calculated the average years of transition and discovered two facts: twenty-eight years for the transition from a lower-middle income to an upper-middle income level and fourteen years from an upper-middle income level to a high income level.

As of 2010, thirty out of thirty-eight lower-middle income countries remained as such for more than twenty-eight years. Five out of fourteen upper-middle income countries stayed in the same income range for more than fourteen years. If looking at Southeast Asian countries, we find that Malaysia is one of the five that may have fallen into the upper-middle-income trap, while Indonesia is in danger of remaining in the lower-middle income trap.

\footnotetext{
${ }^{2}$ A lower-middle-income country having less than $\$ 7,250$ and an upper-middle-income country having more than $\$ 7,250$.
} 


\subsubsection{Several Questions About the Discussion of the Middle-Income Trap}

This paper first considers the example of Malaysia, which is a typical country facing the middle-income trap (Suehiro 2014, pp. 127-129).

Malaysia transitioned into what the World Bank defines as an upper-middleincome country in 1979. It subsequently dropped back down to lower-middle income status, and, although it regained its status as an upper-middle income country in 1991, it has so far been unable to join the group of high-income countries, as the study of Felipe and others has pointed out (Felipe et al. 2012).

Between 2010 and 2015, per capita GDP (current) in Malaysia increased from $\$ 9,069$ to $\$ 9,766$, or by merely $\$ 700$, in contrast with the case of China, which impressively increased per capita GDP from $\$ 4,516$ to $\$ 7,925$ in the same period. Malaysia clearly remains at a standstill compared to Taiwan, which took fifteen years to transition to a high-income country after becoming an upper-middle-income country in 1973, and South Korea, which took fifteen years to transition to a highincome country after becoming an upper-middle-income country in 1978 (Suehiro 2014, p. 128).

This highlights how Malaysia has been caught in the middle-income trap. More precisely, Malaysia has hit the "wall for transitioning to a high-income country" or the high-income hurdle (Suehiro 2014, p. 127). By contrast, Thailand and China both joined the group of upper-middle-income countries in 2010. It is unfair to apply the middle-income trap theory used in relation to Malaysia to countries that have only just become upper-middle-income countries.

Moreover, an issue confronting both of these countries, and an issue for Indonesia, which is on the verge of becoming an upper-middle income country, is the clarification of what policies are required to transition into high-income countries. Lastly, India and Vietnam both finally escaped from the group of low-income countries in 2007 and 2008, respectively, so they cannot be discussed in the same terms as Thailand and China.

At any rate, it is clearly unreasonable for international institutions to group emerging Asian countries together as middle-income countries, and assert that they are all caught in a hidden trap. What instead must be considered are the hidden problems in the growth patterns common to these countries; in other words, the problems of growth limitations grounded in the low-cost advantage.

\subsubsection{From "the East Asian Miracle" to "Innovative East Asia"}

A similar argument to that of the middle-income trap was presented in "The Myth of Asia's Miracle," a paper by Paul Krugman (1994) that aimed to criticize The East Asian Miracle, published by the World Bank (1993). Krugman asserted that the 
previous high growth in East Asia was due to additional inputs of capital and labor, not technical innovation. He thus predicted that if wages in Asia rose and investment efficiency declined, Asian growth would eventually slow down and the "miracle age" would end.

Krugman's prediction came true with the outbreak of the Asian currency crisis three years later, and his thesis became famous overnight. The currency crisis was ultimately attributed to a combination of such international factors as large, speculative movements of short-term international funds and such domestic factors as fragile financial systems and poor corporate governance (Suehiro 2008). It was not a consequence of the higher wages and lower investment efficiency purported by Krugman.

Nevertheless, World Bank economists took the currency crisis as a turning point, considering all East Asian economic development after that time as "input-driven growth" and emphasizing its negative aspects. For example, Yusuf and Evenett (2002, pp. 3-4) asserted the following in Can East Asia Compete?

Except for the low-income economies, innovation will be the engine of growth for much of East Asia now that the initial resource-intensive phase of industrialization is ending [meaning the end of the input-driven growth era]. Innovation in a broad range of areas, from products to services and business organizations, will be the principal source of increases in productivity and in export competitiveness.

Furthermore, they note the importance of tackling three areas: (1) creating an environment that stimulates research and development by public and private entities, (2) integrating the manufacturing sector with the financial and services sectors, and (3) leveraging information and communications technology.

The arguments presented in these reports are virtually the same as the middleincome trap argument that became popular in the early 2010s (Aiyar et al. 2013; Eichengreen et al. 2013). The phenomenon had, therefore, been noted more than 10 years earlier.

\subsection{Higher Wages and Lower Labor Productivity}

\subsubsection{End of the Low-Cost Advantage Era}

The main reason that the ADB and others discussed China from the perspective of the middle-income trap was the pronounced rise in nominal wages starting in the late 2000s. The main attribute of East Asia's economic development is that its industrialization is labor-intensive and focuses on export-oriented industries. Therefore, the ability to continually secure a high-quality labor force at comparatively low wage levels is vital to sustaining East Asian industrialization.

On this point, China has a population of 1.3 billion, with enormous labor reserves living in its countryside. Back around the early 2000s, it was even said that there was no limit to China's labor supply. In fact, farmworkers who have moved from 
rural villages to the city (i.e., 180 million people as of 2011) have supported the development of labor-intensive industries (Kan 2013).

However, a labor shortage appeared in coastal cities' industrial areas in the late 2000s, and both nominal and real wages started to rise. For instance, the nominal wage level among urban workers in China increased from 9,333 yuan per year in 2000 to 36,539 yuan in 2010, and further to 56,360 yuan in 2014 (National Statistical Office, China 2016). Therefore, the rate of wage increase during the 2000s has constantly exceeded ten percent per year.

While the degrees vary, sharp wage increases also occurred in Thailand. For example, in January 2013, the Thai government adopted a policy concerning the minimum wage, increasing it from a daily wage level of between 162 baht (regional provinces) and 215 baht (Bangkok and its surrounding five provinces) to a nationwide uniform figure of 300 baht. While this policy was intended to confirm that wage levels in the capital had already exceeded 300 baht, it also reflected the Thai government's desire to shift to an industrial structure oriented toward technology and knowledgeintensive industries by constraining the entry of foreign companies that were looking for a low-wage labor force.

Furthermore, Thailand had been confronted with a chronic labor shortage since 2000. Therefore, the government not only issued work permits to foreign workers from Cambodia, Laos, and Myanmar (CLM) who had legally entered the country to work, but also gave temporary work permits to illegal immigrants from CLM on the basis of agreements with those countries. These foreign workers were employed in such wide-ranging occupations as fishing, transporting of paddy, harvesting of natural rubber, and construction, as well as in menial jobs in various manufacturing sectors and housework.

According to publicly released data (Ministry of Labour, Office of Foreign Workers Administration), as of 2011, Thailand had 580,000 legal workers and 1.25 million illegal immigrants and people with temporary work permits, for a total of 1.83 million foreign workers, of whom more than eighty percent were from Myanmar. Needless to say, the large presence of foreign workers may become an obstacle to the improvement of labor productivity in Thailand.

\subsubsection{Labor Productivity in East Asia}

Even though wages are rising, economic growth can be maintained as long as increased labor productivity is vital. Two metrics indicate increased labor productivity.

One metric is growth of labor productivity, which is measured as the annual growth rate in the amount of production per capita (the amount of value added). The other is the differential in labor productivity, which is measured by taking the amount of added value produced per capita in the top developed country (the United States) as 100 and looking at how much the same figure for a given country varies from the U.S. figure. 
It is important to note that the annual growth rate in labor productivity has constantly been higher in Asia than in all other regions in the world. According to the review by McMillan and Rodrik concerning an International Labour Organization (ILO) survey, the annual growth rate in labor productivity from 1990 to 2005 averaged $3.87 \%$ for Asia as a whole, and $3.33 \%$ for Asia excluding China. By contrast, labor productivity growth in Latin America was a very low $1.35 \%$ (McMillan and Rodrik 2011). In addition, the figure for Asia was about twice that of the United States $(1.80 \%)$ and Japan $(1.41 \%)$.

The issue to be raised here is not the annual growth rate of labor productivity in general, but the change in the annual growth rate over time. This issue is significant because the growth rate of labor productivity tends to fall when capital stock increases with progress in industrialization. Empirical data are shown in the Productivity Databook of the Asian Productivity Organization (APO 2016), which provides the dataset for each country over four time periods (1990-1995, 1995-2000, 2000-2005, and 2005-2014).

According to this report, all countries apart from China and India are trending downward in their per-hour labor productivity growth using 2011 PPP. ${ }^{3}$ For instance, Thailand has experienced a sharp decline, from 5.2\% in 2000-2005 to 3.2\% in 2005-2014, while Malaysia also showed a similar decline, from 3.1 to $2.3 \%$, in the same period. A downward trend can also be confirmed for South Korea (from 4.3 to $3.5 \%$ ) and Singapore (from 3.7 to only $1.1 \%$ ), which are high-income countries (APO 2016, p. 73).

Still, we cannot necessarily say that China does not have a problem with labor productivity. Taking the United States to be 100 and comparing the amount of added value produced per worker indicates that China was only five in 2000, eleven in 2010, and fifteen even in 2014 (computed from Table 11 in APO, 2016, p. 71). Furthermore, Malaysia was thirty seven in 2014, compared to thirty two in 2000, and Thailand was also low at seventeen as compared to twelve in the same year. What should be noted here is that two countries have hardly shown the development of catching up with the United States over the fifteen years from 2000 to 2014.

One way to reduce the differential in productivity with industrial developed countries is to upgrade the country's industrial structure by shifting the manufacturing sector from low-value-added industries to high-value-added ones. Another way is to switch from an input-driven growth path to an innovation-led growth path.

\footnotetext{
${ }^{3}$ In China, the annual growth rates of labor productivity were $10.3 \%$ in $1990-1995,6.3 \%$ in 1995-2000, 7.7\% in 2000-2005, and 9.0\% in 2005-2014, while India shows 3.1, 4.1, 4.7, and $5.8 \%$ in the corresponding period (APO 2016, p. 73).
} 


\subsection{Innovation and R\&D in East Asia}

\subsubsection{R\&D Activities in Asian NIES, ASEAN Countries, and China}

Innovation can be discussed in terms of the national and corporate levels. This section considers innovation at the national level. Metrics to measure the R\&D activities at the national level include (1) the ratio of R\&D expenditure to nominal GDP, (2) the per capita R\&D expenditure, (3) the number of patent applications and acceptances, (4) the population density of R\&D personnel, and (5) the number of scientific articles published in international peer-refereed journals. These metrics assess whether a particular country is actively innovating.

Table 2.1 highlights the results of the first three of the above-mentioned metrics using data from information on the UNESCO Institute for Statistics (UNESCO STAT) and the World Intellectual Property Organization (WIPO). As the table illustrates, compared with European countries (apart from Sweden), Japan and Asian NIEs have a higher ratio of R\&D expenditure relative to GDP. Regarding international patent applications, the United States still exceeded Japan in 2015, even though the gap between the two countries has narrowed in recent years.

What is most interesting here is the extremely wide gap between the Asian NIEs and ASEAN countries. One indicator of whether a country is science and technology focused is whether its ratio of R\&D expenditure to GDP is more than $2 \%$. As shown in the latest year (2015), Malaysia had 1.30\%, Thailand had $0.63 \%$, and Indonesia was less than $0.1 \%$. This puts these three countries a long way from transitioning to high-income countries.

Another feature common to ASEAN countries is the lack of notable improvement in performance between 2000 and 2015. Pursuing R\&D should have been important national targets for both Malaysia and Thailand. Nevertheless, no results are evident in the two countries in general and in Thailand in particular. There is a striking contrast in this regard when compared to China's performance in both the ratio of R\&D to nominal GDP and the number of international patent applications, indicating that China seeks to be a leading nation in science and technology.

China's technology promotion policy was provided in the "Guidelines on the National Medium-Term and Long-Term Program for Science and Technology Development (2006-2020)," announced in 2006 (Science Portal China 2017). The key words in these guidelines are "indigenous innovation, leapfrogging in priority fields, enabling development, and leading the future." "Indigenous innovation" is not borrowed technology, but refers to the "national innovation capability" to develop domestic new technologies.

At the same time, the government established four major national targets in science and technology: (1) the ratio of R\&D expenditure to GDP will reach $2.5 \%$ by 2020, (2) the contribution of technological progress to GDP growth or total factor productivity will account for $60 \%$ and over, (3) the cost of importing foreign technology against the total cost of developing new technology will account for less than $30 \%$, and 
Table 2.1 R\&D activities in major countries including emerging Asia, 2000 and 2015

\begin{tabular}{l|l|l|l|l|l|l}
\hline Countries/Economies & \multicolumn{2}{l|l}{$\begin{array}{l}\text { R\&D expenditure } \\
\text { against nominal } \\
\text { GDP (\%) }\end{array}$} & \multicolumn{2}{l|}{$\begin{array}{l}\text { R\&D expenditure } \\
\text { per capita (\$) }\end{array}$} & \multicolumn{2}{l}{$\begin{array}{l}\text { International patent } \\
\text { applications (cases) }\end{array}$} \\
\cline { 2 - 7 } & 2000 & 2015 & 2000 & 2015 & 2000 & 2015 \\
\hline Japan & 3.00 & 3.28 & 786 & 1,344 & 9,569 & 44,052 \\
\hline South Korea & 2.18 & 4.23 & 401 & 1,476 & 1,582 & 14,564 \\
\hline Taiwan & 1.90 & 3.06 & 419 & 1,434 & n.a. & n.a. \\
\hline Singapore & 1.82 & 2.20 & 767 & 1,828 & 222 & 907 \\
\hline China & 0.89 & 2.07 & 26 & 298 & 781 & 29,817 \\
\hline Malaysia & 0.46 & 1.30 & 60 & 344 & 5 & 267 \\
\hline Thailand & 0.24 & 0.63 & 18 & 102 & 8 & 133 \\
\hline Indonesia & 0.06 & 0.08 & 3.1 & 8.5 & 9 & 6 \\
\hline Philippines & n.a. & 0.14 & n.a. & 9.1 & 0 & 27 \\
\hline Vietnam & n.a. & 0.37 & n.a. & 19.5 & 1 & 21 \\
\hline India & 0.74 & 0.63 & 15 & 38.3 & 190 & 1,412 \\
\hline Sweden & 3.42 & 3.26 & 930 & 1,564 & 3,090 & 3,841 \\
\hline USA & 2.62 & 2.79 & 953 & 1,563 & 38,015 & 56,995 \\
\hline France & 2.08 & 2.23 & 555 & 945 & 4,137 & 8,417 \\
\hline Germany & 2.39 & 2.88 & 640 & 1,398 & 12,581 & 18,002 \\
\hline
\end{tabular}

Note R\&D expenditure per capita includes both public and private sectors.

Sources R\&D expenditure per GDP and per capita: http://www.globalnote.jp/p-data-g/?dno=1190\& post_no $=10315$ and http://www.globalnote.jp/p-data-g/?dno=2580\&post_no $=10315$ (Original data come from UNESCO STAT). International patent applications: http://www.globalnote.jp/p-data-g/ $? \mathrm{dno}=4240 \&$ post_no $=5380$ (Original data come from the World Intellectual Property Organization)

(4) China will be ranked in the top five, in terms of the number of patents and the citation of scientific articles in peer-refereed international journals. In brief, the Chinese government's stance is completely focused on the creation of a national system of innovation, as Nelson and Freeman have emphasized. ${ }^{4}$

On the other hand, the reference to "leading the future" in the guidelines indicates the government's vision to enable basic research and create new industries from a long-term perspective. They focus on eight fields: biotechnology, information and technology, new materials, advanced manufacturing technologies, advanced energy, maritime technology, laser technology, and space development. These industries are assumed to develop under the dominant role of large-sized state-owned enterprises.

\footnotetext{
${ }^{4}$ Concerning the discussion about the "national system of innovation" on the basis of Japanese experiences, please see Nelson (1993) and Freeman (1995). A brief introduction of these works is seen in Suehiro (2014, pp. 137-139).
} 
Therefore, the government is expected to make a more direct contribution rather than an indirect contribution to innovation. Such an approach is quite different from that in the work of Yusuf and Evenett (2002) and Yusuf (2003), which emphasized the collaboration between the government and the private sector, and the networking between the manufacturing sector and the non-manufacturing sector.

Propelled by this technology promotion policy, China's ratio of R\&D expenditure to GDP successfully exceeded the national target of $2 \%$ in 2014 . Therefore, even though both China and Thailand occasionally became upper-middle-income countries in 2010, China seemed to gain an advantage with regard to advancing to become a high-income country.

\subsubsection{Strategies to Avoid the Middle-Income Trap}

In the next part, three countries_-China, Malaysia, and Thailand-are examined in relation to their strategies of avoiding the middle-income trap, or more exactly, their strategies of the growth pattern of overcoming the low-cost advantage. According to the survey research of Veerayooth (2015), the patterns of avoiding the middle-income trap are classified into three major groups: (A) establishing appropriate education and institutions, (B) changing export composition through comparative advantage, and $(\mathrm{C})$ promoting industrial upgrading through state intervention.

Differences in the three groups are affected by the different roles played by governments in instituting innovative measures. Group $\mathrm{C}$ is characterized by the most active role of government in innovation and industrial upgrading, while group A is characterized by a minimal state role in industrial promotion; rather, the state is expected to facilitate such infrastructure as an educational system for the sake of promoting innovation. Group B maintains a position between group A and group C, where both private firms' efforts (supply side) and the condition of the world market (demand side) are more important. A shift to higher-value-added exports is realized through market mechanisms rather than state intervention (Veerayooth 2015, pp. 56-57).

In this chapter, China is supposed to represent group C, while Malaysia and Thailand belong to group B. It is true that the governments of Malaysia and Thailand have constantly intended to play significant roles in both industrial upgrading and changes in export composition. But new industries and new products have eventually been introduced by foreign firms. In addition, local private firms seem to have discovered their competitive advantages in resource-based industries and the service sector rather than core manufacturing industries. They also seem to have focused on niche products and niche markets rather than new products and new production technology (Khoo Boo Teik et al. 2017).

Comparing two countries in particular reference to the role of government in formulating national economic plans, Malaysia seems to follow the pattern of group $\mathrm{C}$ because the government is empowered to supervise the private sector under the Mahathir administration (Torii 2006). On the other hand, the Thai government is 


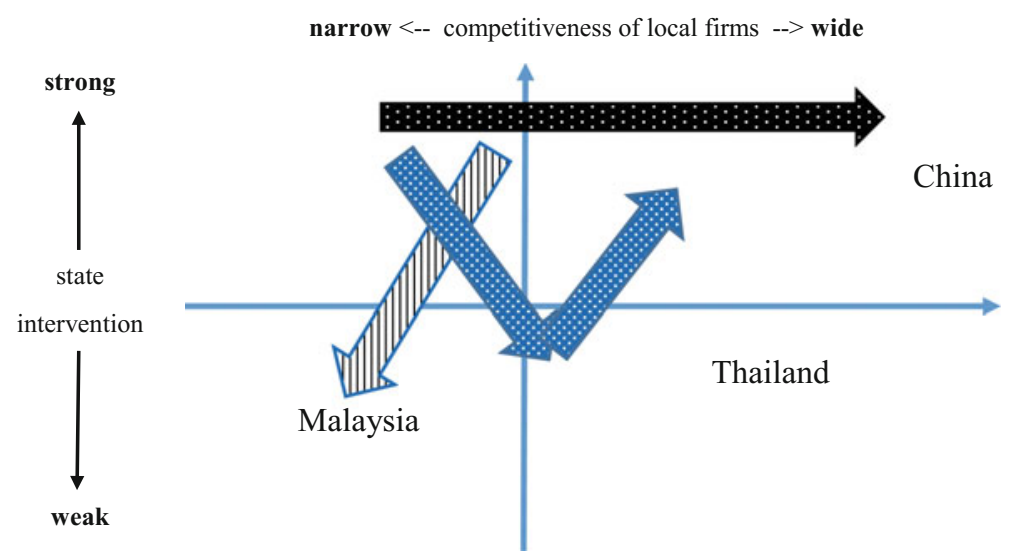

Fig. 2.1 Relationships between the state and local firms. Note Local firms include state and public enterprises. Source Drawn by the author

given the power to support targeted industries through tax incentives and semigovernment institutions (sathaban) under the Thaksin administration (Suehiro 2010). After the military coup d'etat in 2006, the government role was going to decline. However, as will be discussed later, since 2014, the Prayut government has attempted to restore the state leadership in economic development and proposed an ambitious national strategy of "Thailand 4.0." In this sense, Thailand shows the shift from group $\mathrm{C}$ to group $\mathrm{B}$, and then returns to group $\mathrm{C}$ in recent years.

In brief, Malaysia has shifted from the area where the state has been expected to play an active role to the area where the state has eventually played a less important role, while Thailand has indicated the V-shaped curve in terms of degree of state intervention (Fig. 2.1). If we look at the scope or the field where local firms, including state enterprises, will be able to demonstrate their competitiveness in the world market, we find that Thailand seems to show wider fields in comparison to Malaysia, but narrower ones in comparison to China. Keeping these characteristics in mind, let me examine the experience of each country in reference to its government policies of avoiding or overcoming the middle-income trap.

\subsection{Cases of China, Malaysia, and Thailand}

\subsubsection{China: ADB Policy Options}

In Growing Beyond the Low-Cost Advantage: How the People's Republic of China Can Avoid the Middle-Income Trap, the ADB stated that many countries that attained middle-income status could no longer compete with low-income countries because of rising wages on the one hand, and they were also unable to compete with 
Table 2.2 The middle-income trap for China and the ADB policy options, 2012

\begin{tabular}{|c|c|c|}
\hline Fields & Risks and problems & $\begin{array}{l}\text { New direction for long-term } \\
\text { growth }\end{array}$ \\
\hline Productivity & $\begin{array}{l}\text { Large technology and } \\
\text { productivity gaps with } \\
\text { advanced countries }\end{array}$ & \multirow[t]{2}{*}{$\begin{array}{l}\text { PRC growth needs to be } \\
\text { driven increasingly by } \\
\text { productivity improvements } \\
\text { through innovation and } \\
\text { industrial upgrading }\end{array}$} \\
\hline Labor markets and wages & $\begin{array}{l}\text { Rapid rise of wages. PRC is } \\
\text { approaching the so-called } \\
\text { "Lewis turning point" }\end{array}$ & \\
\hline Sources of growth & $\begin{array}{l}\text { Growth has relied too much on } \\
\text { investment (high saving) and } \\
\text { net exports }\end{array}$ & $\begin{array}{l}\text { Shift of the sources of growth } \\
\text { from public investment and } \\
\text { exports to domestic } \\
\text { consumption and service } \\
\text { industries }\end{array}$ \\
\hline Income inequality & $\begin{array}{l}\text { Rising income inequality: Gini } \\
\text { coefficient increased from } 30 \\
\text { in the early } 1980 \text { s to } 43.4 \text { in } \\
2008\end{array}$ & $\begin{array}{l}\text { Reducing income inequality to } \\
\text { make growth more inclusive; } \\
\text { enhancing governance }\end{array}$ \\
\hline Pressures on natural resources & $\begin{array}{l}\text { Rapid growth has created } \\
\text { pressure on its natural } \\
\text { resources and the environment } \\
\text { (water shortage, air pollution) }\end{array}$ & $\begin{array}{l}\text { Promoting green growth to } \\
\text { conserve resources and protect } \\
\text { the environment }\end{array}$ \\
\hline $\begin{array}{l}\text { External economic } \\
\text { environment }\end{array}$ & $\begin{array}{l}\text { As the world's second largest } \\
\text { economy, impact of the PRC } \\
\text { becomes significant }\end{array}$ & $\begin{array}{l}\text { Strengthening international } \\
\text { and regional economic } \\
\text { cooperation }\end{array}$ \\
\hline General & $\begin{array}{l}\text { Weakness in governance and } \\
\text { institutions to support the } \\
\text { long-term growth }\end{array}$ & $\begin{array}{l}\text { Deepening structural reforms: } \\
\text { reforms of enterprises, labor } \\
\text { and land markets, the financial } \\
\text { sector, and the fiscal system }\end{array}$ \\
\hline
\end{tabular}

Source Summarized by the author based on information from ADB (2012b)

high-income countries because they had not shifted into higher-value production through innovation and industrial upgrading. This is just the middle-income trap, and China is going to be caught in it as well (ADB 2012b, p. 3).

Table 2.2 summarizes the points highlighted in the report in association with major issues China faces in transitioning into a high-income country.

The ADB listed seven risks and problems for China: (1) large productivity gaps as compared to advanced countries (see also Sect. 3 of this chapter), (2) labor market changes and the rapid rise in wages (see Sect. 2.2), (3) a growth pattern that relies excessively on public investment and exports, (4) widening domestic income inequality, (5) exploitation of natural resources and environmental degradation, (6) an international backlash against the rapid growth in China's presence in the world economy, and (7) the weakness of institutions in supporting long-term growth. These 
elements almost duplicate the items listed in the World Bank's China 2030 report (World Bank et al. 2012).

The measure that is stressed the most in the report is productivity improvement through innovation and upgrading of the industrial structure. The report also proposes the adoption of three strategies: (1) inclusive growth to reduce income inequality, (2) a shift from a growth path that has relied too much on public investment and exports of industrial goods to one based on increasing domestic demand and developing the service sector, and (3) environmentally friendly growth (green growth) that both conserves resources and protects the environment.

Still, these economic challenges are very broad, although China has started the state-led policy of developing self-reliance technology. Among the seven policy issues in Table 2.2, the most important one is probably structural reform. However, structural reform is a problem that lies at the root of the socialist system (Kan 2013). The implementation of a "reform and open" path provides the dream and incentives for economic growth shared by both corporations and Chinese citizens, but the pain that accompanies structural reform creates conflicts of interest for related parties. Considering such difficulties, China's path of transition to a high-income country is not necessarily going as smoothly as was projected in the government long-term plan on the development of science and technology.

\subsubsection{Malaysia: From "National Vision Plan" to a "New Economic Model"}

Malaysia seems to have been caught in the middle-income trap, as was pointed out in Sect. 2.1 of this chapter. Under the Mahathir administration, the economy achieved a certain degree of success, with growth in production and exports of industrial goods, mainly from the home appliance and electronics sector, as well as rectification of inequalities between ethnic groups under policies favoring ethnic Malays (the Bumiputera Policy) (Torii 2006). However, there has clearly been an economic stagnation since the 2000s.

Let's compare the growth rates of two periods on either side of the 1997 Asian currency crisis: the ten years from 1987 to 1996 and the ten years from 2000 to 2009. In the ten years before the Asian currency crisis, the annual growth rate for Malaysia's manufacturing sector was $13.9 \%$, which was higher than that of China $(12.6 \%)$, Thailand (11.8\%), and Vietnam (6.6\%).

However, in the decade starting in 2000, Malaysia's growth rate plummeted to $3.7 \%$, which was lower than that of China (10.8\%), Vietnam $(10.5 \%)$, and Thailand (5.6\%). The same is true for the annual growth rate of exports. Malaysia's annual rate of export growth was $11 \%$ from 2000 to 2009 . This was not only below that of booming China (23\%) and Vietnam (21\%), but also below that of Thailand (14\%).

Yusuf and Nabeshima (2009) attributed this economic stagnation to the bias of export products toward electric and electronic goods. While the makeup of Malaysia's 
exports was similar to that of other East Asian countries and economies (and competition with China was severe), little progress was made toward diversification, there was no shift towards high-value-added export products, and personnel was not trained to develop new technologies and new products.

The electric and electronics sectors, which drove the Malaysian economy, grew into a large industry accounting for more than $70 \%$ of manufactured exports and more than $50 \%$ of total exports at the end of the 1990s. However, after Seagate (the largest manufacturer of hard disk drives in the world) closed its plant in 2000, Intel, Motorola, and Dell all either shrunk their operations or closed their plants by 2001, shifting their production bases to China (Yusuf 2003, p. 294). In 2002, Malaysia ceded to China its title as the number one exporter of PCs to the U.S. market.

The most serious issue for Malaysia was the high proportion of foreign workers, mostly employees from Indonesia, in the manufacturing sector. The percentage of foreign workers, which accounted for a mere $2 \%$ in 1990, rose to $21 \%$ in 2004 and surpassed $28 \%$ in 2008. Migrant foreign workers are thought to have hardly contributed to the improvement of labor productivity. This is because they have no incentives due to their short-term employment contracts and their unstable working status. As a result, the Malaysian government froze new employment of foreign workers in 2009, when the number of foreign workers totaled 2.3 million, and set a policy to reduce it to 1.5 million by 2015 (Tham and Loke 2011).

Nevertheless, the number of foreign migrant workers in unskilled fields remains at a very high level. According to the latest survey of the ILO, the ratio of migrant employment to total manufacturing employment was $37 \%$ in 2009 , and $34 \%$ even in 2014 (ILO 2016, p. 2). ${ }^{5}$

To deal with this situation, the Najib administration announced its New Economic Model (NEM) in March 2010 following the expiry of the National Vision Plan (NVP, 2001-10), which was aimed at correcting the economic inequalities between ethnic groups. At the same time, the government embarked on the Economic Transformation Programme (ETP), which sought an escape from the middle-income trap.

Comparing the NEM with the National Development Plan (NDP, 1991-2000) and NVP, the NEM under the Najib administration consists of seven strategies. It is a radical transformation that involves a shift (1) from an investment-driven growth path to a productivity-focused growth path, (2) from being government driven to private sector led, (3) from centralization to local autonomy, (4) from a focus on balanced regional growth to the creation of strategic clusters, (5) from favoring specific industries and companies (steel, cement, automobiles, etc.) to favoring technologically capable industries and companies, (6) from an export focus on the G3 market (Europe, the United States, and Japan) to a focus on markets within Asia; and (7) from relying on foreign workers to selectively appointing foreign specialists and attracting skilled professionals from overseas (National Economic Advisory Council, Malaysia 2010).

\footnotetext{
${ }^{5}$ To tackle this problem, the Eleventh Malaysia Plan (2016-2020) has stated that a comprehensive immigration policy for foreign workers will be developed, with the Ministry of Human Resources (MOHR) assuming the lead role in policy making (Othman and Rahim 2014).
} 
Among the aforementioned policies, the productivity-focused growth path in item (1) is the same as the policy proposals made by the ADB in relation to China. In other words, the aim is to revise the input-driven growth path. Meanwhile, items (2) to (5) aim at correcting the distortions in resource allocation resulting from the Bumiputera Policy (in the New Economic Plan or NEP for 1971-90, NDP and NVP) so that the economic structure is in tune with the era of globalization.

However, there is strong resistance to revising the Bumiputera Policy, even from within the ruling party. In addition, the percentages of $R \& D$ expenditure against nominal GDP are stagnant-1.03\% in 2010 and $1.30 \%$ in 2015, lower by far than those of China (see Table 2.1). As Kawano introduced interesting examples of local private firms' activities in the natural rubber industry, Malaysia has begun to promote notable innovation in resource-based industries (Kawano 2017). However, carefully examining these case studies, we recognize that local private firms (Top Glove and Kossan) have mainly developed niche products, such as medical surgical gloves, with the improvement of imported technology rather than new products with new production technology.

In core manufacturing industries such as the automotive industry, the government has not been successful in inviting new multinational corporations into Malaysia after the Asian currency crisis. Reviewing these elements, Malaysia is likely to face a much harder path of transition into a high-income country than China.

\subsubsection{Thailand: Pursuing Thai-ness and Next-Generation Industries}

In May 2014, a Thai military group launched a coup d'etat to stop unproductive political conflict between pro- and anti-Thaksin groups that started in 2013. Under the Prayut Chan-ocha government, the special economic team led by Deputy Prime Minister Somkid Jatusripitak ${ }^{6}$ and the Ministry of Industry rearranged the previous policies and provided a new long-term national strategy in order to truly overcome the middle-income trap. This national strategy is called "Thailand 4.0" and combines the ideas of the creative economy of the NESDB, the promotion of next-generation industries proposed by the Board of Investment, and rehabilitation of the Eastern Seaboard Industrial Development projects (now known as the Eastern Economic Corridor or EEC project). ${ }^{7}$ The idea of Thailand 4.0 is summarized in Fig. 2.2.

From 2006 to 2015, the Thai manufacturing sector has suffered low-level growth: annual growth rates are $3.0 \%$ for manufacturing industries, $2.0 \%$ for investments in these industries, $5.4 \%$ for manufactured exports, and a mere $0.7 \%$ for total factor productivity (TFP). To overcome such economic stagnation or the so-called middle-

\footnotetext{
${ }^{6}$ Somkid had served as finance minister and deputy prime minister for the Thaksin administration between 2001 and 2006 .

${ }^{7}$ For the national strategy of Thailand 4.0 and the EEC project, please see Ministry of Industry (2016, 2017) and Kanit (2017).
} 


\begin{tabular}{|c|c|c|c|c|c|}
\hline \multicolumn{2}{|c|}{$\begin{array}{l}\text { Actual annual growth rates, } \\
\qquad 2006-2015(\%)\end{array}$} & \multirow{2}{*}{$\begin{array}{c}\text { Three Traps } \\
\begin{array}{c}\text { Middle-income } \\
\text { trap }\end{array}\end{array}$} & \multirow{2}{*}{$\begin{array}{c}\begin{array}{c}\text { Strategic } \\
\text { responses }\end{array} \\
\begin{array}{c}\text { Innovation- } \\
\text { driven growth }\end{array}\end{array}$} & \multicolumn{2}{|c|}{$\begin{array}{c}\text { Long-term target for 2017- } \\
36(\%)\end{array}$} \\
\hline $\begin{array}{l}\text { Industrial annual } \\
\text { growth }\end{array}$ & 3.0 & & & $\begin{array}{l}\text { GDP annual } \\
\text { growth }\end{array}$ & 4.5 \\
\hline $\begin{array}{l}\text { Investment in } \\
\text { MFG growth }\end{array}$ & 2.0 & Inequality trap & Inclusive growth & $\begin{array}{l}\text { Investment } \\
\text { growth }\end{array}$ & 10.0 \\
\hline $\begin{array}{l}\text { Manufacture } \\
\text { exports growth }\end{array}$ & 5.4 & Imbalance trap & Green growth & Exports growth & 8.0 \\
\hline $\begin{array}{l}\text { Total Factor } \\
\text { Productivity }\end{array}$ & 0.7 & & & $\begin{array}{l}\text { Total factor } \\
\text { productivity }\end{array}$ & 2.0 \\
\hline
\end{tabular}

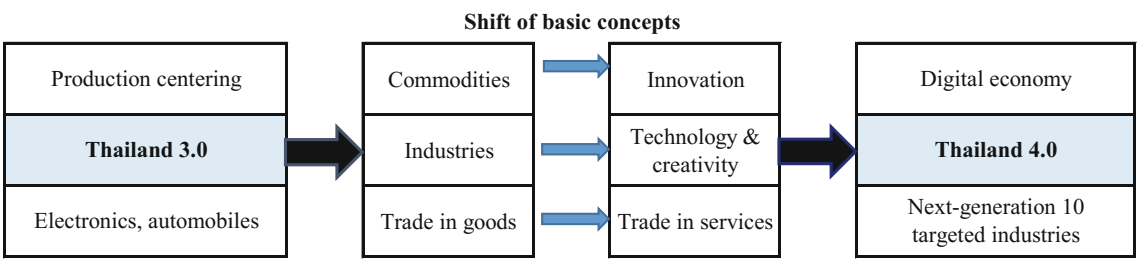

Fig. 2.2 Thailand 4.0 and Long-term Economic Strategy, 2017-2036. Sources Constructed by the author on the basis of the Ministry of Industry, Thailand (2016)

income trap, Thailand is expected to shift the stage of economy from Thailand 3.0, based on production centering, to Thailand 4.0, based on the digital economy, by focusing policy targets on innovation, technology and creativity, and trade in services.

To implement this policy, the Prayut government enacted the National Strategy Act (Prarachabanyat Yutthasat Chart) in July 2017, which empowered political leaders such as Prayut to manage national matters in the next twenty years beyond the authority of each cabinet organized through general election. Indeed, the national strategy committee members consist of the prime minister (chairperson); two deputy prime ministers (vice chairpersons); the chair of the National Security Council; commanders of the army, navy, and air force; representatives of business associations such as the Thai Federation of Industries; and top leaders of large local firms such as the CP Group and the Siam Cement Group. ${ }^{8}$ This act clearly indicates that the Prayut government intends to create strong state leadership in economic fields and is following the Chinese model (state intervention or group C).

Essential projects in Thailand 4.0 are the promotion of next-generation industries (ten industries) and the introduction of the Eastern Economic Corridor or EEC project. As shown in Table 2.3, the targets of next-generation industries include five existing industries and five future industries.

Types of targeted industries overlap substantially with those of China's longterm program for science and technology development (see Sect. 2.3). However, the development of such high-tech industries as next-generation automotives, smart electronics, robotics, biochemicals, and the digital economy will depend crucially

\footnotetext{
${ }^{8}$ See "Prarachabanyat Kan Jat-tham Yutthasat Chart" in Rachakichanubeksa (Government Gazette) 134, no. 79, Ko, 31 July 2017, pp. 1-12.
} 
Table 2.3 Comparison of eleven targeted industries (1997) and ten targeted industries (2015)

\begin{tabular}{|c|c|c|c|}
\hline \multicolumn{2}{|c|}{$\begin{array}{l}\text { Eleven targeted industries in the industrial } \\
\text { restructuring plan }\end{array}$} & \multicolumn{2}{|c|}{$\begin{array}{l}\text { Ten targeted Next-Generation Industries @ } \\
\text { Depending on FDI }\end{array}$} \\
\hline \multicolumn{2}{|c|}{$\begin{array}{l}\text { (Adopted by a cabinet meeting in November } \\
\text { 1997) }\end{array}$} & \multicolumn{2}{|c|}{$\begin{array}{l}\text { (Adopted by a cabinet meeting in November } \\
\text { 2015) }\end{array}$} \\
\hline 1 & Food, food processing & \multicolumn{2}{|c|}{$\begin{array}{l}<\text { The first stage }>\text { enhancement of existing } \\
\text { industries }\end{array}$} \\
\hline 2 & Textiles, dyeing, and bleaching & 1 & Next-generation automotives $(0$ \\
\hline 3 & Garments & 2 & Smart electronics $\bigcirc$ \\
\hline 4 & Sport shoes and footwear & 3 & Medical and wellness tourism \\
\hline 5 & Leather and leather products & 4 & Agriculture and biotechnology \\
\hline 6 & Plastic products & 5 & $\begin{array}{l}\text { Food for the future and food } \\
\text { processing }\end{array}$ \\
\hline 7 & Precious stones and jewelry & \multicolumn{2}{|c|}{$<$ The second stage $>$ nursing the future industries } \\
\hline 8 & Ceramics and glass products & 6 & Robotics @ \\
\hline 9 & Medical and chemical products & 7 & Logistics and aviation $(0$ \\
\hline 10 & Electronics and electricals & 8 & Biofuels and biochemicals $\bigcirc$ \\
\hline \multirow[t]{2}{*}{11} & Auto parts & 9 & Digital economy @ \\
\hline & & 10 & Medical hub @ \\
\hline
\end{tabular}

Sources Suehiro (2000, p. 45) and the Ministry of Industry (2017, p. 21)

on the regional strategy of multinational corporations and their decisions with regard to new investment in Thailand. Local firms, even large firms, can appeal their advantages in medical and wellness tourism, agriculture and biotechnology, and food for the future, as Arkhom Termpittayapaisith addressed in his treatise on the creative economy (Arkhom 2011). Frankly speaking, however, local firms have neither the capacity to sustain nor practical experience in core future industries.

On the other hand, the EEC projects seem to face similar limitations to the promotion of next-generation industries. The EEC has planned fifteen investment projects (deep seaports, a high-speed train, an aviation industry, tourism, new cities, etc.) amounting to as much as 1,500 billion baht or US $\$ 43$ billion (Ministry of Industry 2017, p. 11). Meanwhile, the government expects most of the investment funds to come from local and foreign private firms. Both the promotion of next-generation industries and the EEC project are closely connected not only with state leadership, but also with the movement of local large firms as well as multinational firms.

In this context, the author's recent work is important (Suehiro 2017). After examining the possibility of Thai firms demonstrating their advantages, I pointed out three major fields: (1) oil refineries, natural gas, and petrochemicals under the control of the PPT (the former Petroleum Authority of Thailand) group or government-linked companies; (2) export-oriented agro-industry, including new energy industries based on biotechnology; and (3) service industries based on 
Thai-ness and Thai hospitality, such as tourism, medical and health-care services, fast food, housing, and entertainment.

Several industries that favor Thai firms are included in the next-generation industries as we see agro-industry, food processing (food for the future), and medical and wellness tourism. Typical cases are the Charoen Pokphand (CP) Group of the Chearavanont family, the Central Group of the Chirathivat family, the TCC Group of the Sirivadhanabhakdhi family, and the Bangkok Dusit Medical Service, or BDMS Group, of the Prasartthong-Osoth family.

These groups are active in developing new products as we see agro-industry in collaboration with government-sponsored institutions (Intarakumnerd 2018). They also are very active in promoting their overseas activities in ASEAN countries in general, and in CLMV (Cambodia, Laos, Myanmar, and Vietnam) in particular. They look for new business opportunities in manufacturing and non-manufacturing by constructing strategic business alliances with large Chinese firms (Suehiro 2017). More importantly, large Thai firms can demonstrate wider fields of competitiveness in agro and service industries in comparison to Malaysian firms (see Fig. 2.1).

However, these groups have no competitiveness in high-tech industries. If these groups advance into fields such as high-speed trains, next-generation automotives, robotics, and the digital economy, they need full support from foreign firms_-Japanese, Western, and Chinese corporations - in both investment funds and technology. ${ }^{9}$ This is quite different from the case of China, where the government aims at promoting a self-reliant type of development in science and technology.

\subsection{The Role of the State in New Challenges}

Computing the average annual growth rates for the three countries in the 16 years from 2000 to 2015 , China shows the best economic performance $(9.5 \%)$, followed by Malaysia $(5.1 \%)$ and Thailand $(4.1 \%) .{ }^{10}$ As compared to the average figure in the world (3.79\%), Thailand still maintains a better position. However, the increased rate of per capita GDP in Thailand between 2010 and 2015 is merely $114 \%$ (from US $\$ 5,112$ to US\$5,816), lower than the average figure of upper-middle-income countries, $124 \%$ ( $\$ 6,240$ to $\$ 7,737)$.

Malaysia suffered the lowest rate of $108 \%$, but its absolute level of per capita GDP of US\$9,766 in 2015 is the nearest position to the rate of high-income countries ( $\$ 12,736$ and over, according to the World Bank's definition). It is apparent that Thailand is far behind Malaysia.

Contrary to the expectations of Yusuf and Evenett (2002), in emerging Asia, the role of the state was not replaced by flexible networking of various actors in manufacturing, services, and academic circles. Rather, as the case of China apparently

\footnotetext{
${ }^{9}$ For instance, the Chinese Alibaba Group led by Jack Ma promised the Prayut government with a full support to the plan of digital economy development in the EEC projects in April 2018.

${ }^{10}$ These figures are computed from the IMF (2016).
} 
demonstrates, the state has continued to play its active role in promoting a national system of innovation, and in otherwise facilitating the institutions' support of private firms' innovation.

Under the Thaksin administration (2001-2006), Thailand also formulated the National Competitiveness Plans on the basis of a partnership between the public and private sectors (Suehiro 2010). This ambitious plan is comparable to the 10-year national plan, "Made in China 2025," to transform Chinese manufacturing industries into the strongest ones in the world. However, the military coup d'etat took place in September 2006, ending the Thaksin government and the state leadership in economic fields.

Since the military coup d'etat in May 2014, the Prayut government has successfully realized political stability throughout the whole country, but has failed to bring about economic recovery. To overcome economic stagnation, in May 2015 Prime Minister Prayut appointed Somkid Jatusripitak as deputy prime minister in charge of economic fields. Under the initiative of a special economic team led by Somkid, Thailand seems to have restored strong leadership of the state in economic fields. However, as we look at the movement of local firms, it is not easy to construct a strong partnership between the public and private sectors.

Furthermore, Thailand must also tackle emerging social problems, such as expanding economic inequalities, the high-speed progress of becoming an aging society, and a worsening environment. As depicted in Fig. 2.2, Thailand is expected to pursue both an inclusive growth strategy and a green growth strategy, in addition to an innovation-led growth strategy to overcome the middle-income trap. This policy option was expressed in the NESDB's 20-year national strategy (2017-2036) that was published in May 2016. The direction of this plan is quite different from Thailand 4.0, which focuses on industrial development rather than social development (NESDB 2016). Such a dual structure in national targets will make it difficult for Thailand to achieve the targeted growth of $4.5 \%$ that was announced in Thailand 4.0 (See Fig. 2.2).

The World Bank optimistically predicted that China would transition to a highincome country in the mid-2020s (World Bank et al. 2012). It is highly likely that Thailand's transition to a high-income country will be later than China's and even Malaysia's. On the other hand, the direction being targeted by Thai local firms and their choice of fields with competitive advantage are much clearer than Malaysia's. At the same time, it is true that the projects of EEC are beyond the capacity of Thai local firms and are essentially determined by the regional strategy of foreign firms.

This fact suggests to us that Thailand is possibly seeking a different path from China, namely, not becoming a high-income country with a relatively high economic growth rate, but instead remaining an upper-middle-income country with a moderate economic growth rate. The latter is a more realistic path for a country and puts less of a burden on the Thai people. 
Even though Thailand's income level stalls at that of an upper-middle-income country (approximately $\$ 13,000$ ), I do not think this would be a wrong choice for the Thai people if Thailand can find its own place within Asian markets and use this position to gain social development. This is because I do not see a transition to a high-income country as the only path available for upper-middle-income countries.

\section{References}

ADB (Asian Development Bank). 2012a. Asia 2050: Realizing the Asian Century. Manila: ADB. ADB. 2012b. Growing Beyond the Low-Cost Advantage: How the People's Republic of China Can Avoid the Middle-Income Trap. Manila: ADB.

APO (Asian Productivity Organization). 2016. APO Productivity Data Book 2016. Tokyo: APO.

Aiyar, Shekhar, Romain Duval, Damien Puy, Yiqun Wu, and Longmei Zhang. 2013. Growth Slowdowns and the Middle-Income Trap. IMF Working Paper No. 13/71, March. Washington, D.C.: International Monetary Fund.

Arkhom Termpittayapaisith. 2011. Setthakit Sarngsan khong Thai [Thailand's Creative Economy]. Bangkok: National Economic and Social Development Board, March.

Eichengreen, Barry, Donghyun Park, and Kwanho Shin. 2013. Growth Slowdowns Redux: New Evidence on the Middle-Income Trap. NBER Working Paper 18673. Cambridge, Mass.: National Bureau of Economic Research, January.

Felipe, Jesus, Arnelyn Abdon, and Utsav Kumar. 2012. Tracking the Middle-Income Trap: What Is It, Who Is in It, and Why? Working Paper No. 715. New York: Levy Economics Institute of Bard College, April.

Freeman, Chris. 1995. The 'National System of Innovation' in Historical Perspective. Cambridge Journal of Economics 19 (1): 5-24.

Gill, Indermit, and Homi Kharas. 2007. An East Asian Renaissance: Ideas for Economic Growth. Washington, D.C.: World Bank.

IMF (International Monetary Fund). 2016. World Economic Outlook April 2016: Too Slow for Too Long. Washington D.C.: IMF

Intarakumnerd, Patarapong. 2018. Mismanaging Innovation Systems: Thailand and the MiddleIncome Trap. London: Routledge.

ILO (International Labour Organization). 2016. Review of Labour Migration Policy in Malaysia. Bangkok: ILO Regional Office for Asia and the Pacific.

Kan, Siyu. 2013. Chugoku futatsu no wana: machiukeru rekishiteki tenkan [Double Traps Faced by China: Historical Transformation Is Coming]. Tokyo: Nihon Keizai Shimbunsha.

Kanit Sangsubhan. 2017. Eastern Economic Corridor: The Prime Gateway to Asia. Bangkok: EEC Office, 22 Aug.

Kawano, Motoko. 2017. Upgrading Malaysia's Rubber Manufacturing Industry: Unlocking Opportunities and Meeting Challenges. In ed. Khoo, Tsunekawa and Kawano.

Khoo Boo Teik, Keiich Tsunekawa, and Motoko Kawano (eds.). 2017. Southeast Asia Beyond Crises and Traps: Economic Growth and Upgrading. London: Palgrave Macmillan.

Krugman, Paul. 1994. The Myth of Asia's Miracle. Foreign Affairs 73 (6): 62-78.

McMillan, Margaret, and Dani Rodrik. 2011. Globalization, Structural Change, and Productivity Growth. Geneva: ILO.

Ministry of Industry, Thailand. 2016. Yutthasat Kan Phatthana Utsahakam Thai 4.0 Raya 20 Pi: Pho.So. 2560-2579 [Thailand Industry 4.0 Strategy: Long-Term 20 Years, 2017-2036]. Bangkok: Ministry of Industry, October. 
Ministry of Industry, Thailand. 2017. Eastern Economic Corridor Development Project: Driving Forward. Bangkok: Ministry of Industry, 15 Feb.

Ministry of Labour, Office of Foreign Workers Administration, Thailand (Samnak Borihan Raengngan Tang-dao). 2012. Phon-kan Phijarana Anuyat Kan Tham-ngan khong Khon Tangdao Prajam Pi 2544-2554 [Survey Results of the Foreign Worker's Work Permit 2001-2011]. Bangkok: Office of Foreign Workers Administration.

National Economic Advisory Council (NEAC), Malaysia. 2010. New Economic Model for Malaysia Part I: Strategic Policy Directions. Putrajaya, Malaysia: NEAC.

NESDB (National Economic and Social Development Board), Thailand. 2016. Rang Krop Yutthasat Chat Raya 20 Pi: Pho.So. 2560-2579 [Draft of Twenty-years Strategy, 2017-2036)]. Bangkok: NESDB.

National Statistical Office, China. 2016. Statistical Yearbook of 2015. Beijing: NSO.

Nelson, Richard R. (ed.). 1993. National Innovation Systems: A Comparative Analysis. New York: Oxford University Press.

Othman, Siti Awanis, and Abdul Rahim Rahim. 2014. Migrant Workers in Malaysia: Protection of Employers. Pertanika Journal of Social Sciences and Humanities 22 (S): 271-282.

Science Portal China. 2017. Kokka chuchoki kagaku gijyutsu hatten kikaku koyo 2006-2020 [Guidelines on the National Medium-Term and Long-Term Program for Science and Technology Development (2006-2020)]. www.spc.jst.go.jp/policy/science_policy/chapt3/3_01/3_1_1/3_1_ 1_1.html. Accessed 13 Oct 2017.

Suehiro, Akira. 2000. Tai no keizai kaikaku: sangyo kozo chosei jigyo to chushokigyo shien [Economic Reforms in Thailand: Industrial Restructuring Plan and Support for SMEs]. Shakai Kagaku Kenkyu 51(3): 25-65. Institute of Social Science, the University of Tokyo.

Suehiro, Akira. 2008. Catch-Up Industrialization: The Trajectory and Prospects of East Asian Economies. Singapore: National University of Singapore Press.

Suehiro, Akira. 2010. Industrial Restructuring in Thailand: Japanese or American Approach. In Sustainability of Thailand's Competitiveness: The Policy Challenges, ed. Patarapong Intarakumnerd and Yveline Lecler, 129-173. Singapore: ISEAS.

Suehiro, Akira. 2014. Shinko Ajia keizai-ron: kyacchi-appu wo koete [Newly Emerging Asian Economies: Beyond the Catch-Up Industrialization Approach]. Tokyo: Iwanami Shoten.

Suehiro, Akira. 2017. New Strategy of Thai Big Firms in the Era of ASEAN Economic Community: Another Way of Avoiding the Middle-Income Trap. In ed. Khoo, Tsunekawa and Kawano.

Tham, Siew-Yean, and Heng Loke Wai. 2011. Industrial Deepening in Malaysia: Policy Lessons for Developing Countries. Asian Development Review 28 (2): 88-109.

Torii, Takashi, ed. 2006. Mahatiiru seiken-ka no Maresia: 'isuramu senshinkoku' wo mezashita 22 nen [Malaysia under the Mahathir Administration: 22 Years of Striving to Make Malaysia an Advanced Country with Islamic Value]. Chiba: Institute of Developing Economies, JETRO.

UNESCO STAT (UNESCO Institute for Statistics). n.d. Science, Technology and Innovation, Research and Development. http://uis.unesco.org/en/topic/research-and-development. Accessed 13 Oct 2017.

Veerayooth Kanchoochat. 2015. The Middle-Income Trap and East Asian Miracle Lessons. In Rethinking Development Strategies after the Financial Crisis, Vol.1: Making the Case for Policy Space. In ed. Alfredo Calcagno et al. New York: United Nations.

World Bank. 1993. The East Asian Miracle: Economic Growth and Public Policy. New York: Oxford University Press.

World Bank and Development Research Center of the State Council, People's Republic of China. 2012. China 2030: Building a Modern, Harmonious, and Creative High-Income Society. Washington, D.C.: World Bank. 
WIPO (World Intellectual Property Organization). n.d. Intellectual Property Statistics. www.wipo. int/ipstats/en/. Accessed 1 Oct 2017.

Yusuf, Shahid (ed.). 2003. Innovative East Asia: The Future of Growth. Washington, D.C.: World Bank.

Yusuf, Shahid, and Simon J. Evenett. 2002. Can East Asia Compete? Innovation for Global Markets. Washington, D.C.: World Bank.

Yusuf, Shahid, and Kaoru Nabeshima. 2009. Tiger Economies under Threat: A Comparative Analysis of Malaysia's Industrial Prospects and Policy Options. Washington, D.C.: World Bank.

Open Access This chapter is licensed under the terms of the Creative Commons AttributionNonCommercial-NoDerivatives 4.0 International License (http://creativecommons.org/licenses/bync-nd/4.0/), which permits any noncommercial use, sharing, distribution and reproduction in any medium or format, as long as you give appropriate credit to the original author(s) and the source, provide a link to the Creative Commons license and indicate if you modified the licensed material. You do not have permission under this license to share adapted material derived from this chapter or parts of it.

The images or other third party material in this chapter are included in the chapter's Creative Commons license, unless indicated otherwise in a credit line to the material. If material is not included in the chapter's Creative Commons license and your intended use is not permitted by statutory regulation or exceeds the permitted use, you will need to obtain permission directly from the copyright holder.

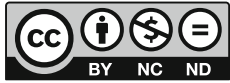

